\title{
Ozone and ozone injury on plants in and around Beijing, China
}

\author{
Wuxing Wan ${ }^{\mathrm{a}, \mathrm{b}, *}$, W.J. Manning ${ }^{\mathrm{c}}$, Xiaoke Wang ${ }^{\mathrm{a}}$, Hongxing Zhang ${ }^{\mathrm{a}}$, Xu Sun ${ }^{\mathrm{a}}$, \\ Qianqian Zhang ${ }^{\mathrm{d}}$ \\ a State Key Laboratory of Urban and Regional Ecology, Research Center for Eco-Environmental Sciences, Chinese Academy of Sciences, Beijing 100085, China \\ ${ }^{\mathrm{b}}$ College of Life Science, Hebei Normal University, Shijiazhuang 050016, China \\ ${ }^{\mathrm{c}}$ Stockbridge School, University of Massachusetts, Amherst, MA 01003, USA \\ d Institute of Hydrogeology and Environmental Geology, Chinese Academy of Geological Science, Shijiazhuang 050061, China
}

\section{A R T I C L E I N F O}

\section{Article history:}

Received 18 December 2013

Received in revised form

15 February 2014

Accepted 28 February 2014

\section{Keywords:}

Ambient ozone

Ozone effect

Plants

Injury symptoms

Beijing

\begin{abstract}
A B S T R A C T
Ozone $\left(\mathrm{O}_{3}\right)$ levels were assessed for the first time with passive samplers at 10 sites in and around Beijing in summer 2012. Average $\mathrm{O}_{3}$ concentrations were higher at locations around Beijing than in the city center. Levels varied with site locations and ranged from 22.5 to $48.1 \mathrm{ppb}$ and were highest at three locations. Hourly $\mathrm{O}_{3}$ concentrations exceeded $40 \mathrm{ppb}$ for $128 \mathrm{~h}$ and $80 \mathrm{ppb}$ for $17 \mathrm{~h}$ from 2 to 9 in August at one site, where it had a real-time $\mathrm{O}_{3}$ analyzer. Extensive foliar $\mathrm{O}_{3}$ injury was found on 19 species of native and cultivated trees, shrubs, and herbs at 6 of the 10 study sites and the other 2 sites without passive sampler. This is the first report of $\mathrm{O}_{3}$ foliar injury in and around Beijing. Our results warrant an extensive program of $\mathrm{O}_{3}$ monitoring and foliar $\mathrm{O}_{3}$ injury assessment in and around Beijing.
\end{abstract}

() 2014 Elsevier Ltd. All rights reserved.

\section{Introduction}

Episodes of high concentrations of particulate and gaseous pollutants, referred to as smog, occur frequently in Beijing, raising concerns about effects on human health. Ozone $\left(\mathrm{O}_{3}\right)$ is a major part of this complex urban pollution mixture. Ozone levels increased at a rate of $1.1 \pm 0.5 \mathrm{ppb} /$ year from 2001 to 2006 (Tang et al., 2009). Ozone levels have been increasing significantly from 2002 to 2010 in China (Wang et al., 2011; Wang et al., 2012a,b,c; Xu and Zhang, 2006). The new air quality standards for $\mathrm{O}_{3}$ for China established in 2012 says that an $8 \mathrm{~h}$ average of $80 \mathrm{ppb}$ and an hourly average of $50 \mathrm{ppb}$ are allowed for the First Grade Standard for nature reserves and scenic areas, and $100 \mathrm{ppb}$ and $80 \mathrm{ppb}$ for the Second Grade Standard for most areas, separately (GB 3095-2012). The higher value is permitted in the new standard than in the old one (GB 3095-1996). It reflected the incidence of high levels of ambient $\mathrm{O}_{3}$ in China.

The effects of $\mathrm{O}_{3}$ on crop plants and some tree seedlings have been reported from controlled field experiments with Open-Top Chambers and Free-Air Exposure Systems in China (Wang et al., 2007; Tang et al., 2011). Little is known about the effects of

\footnotetext{
* Corresponding author.

E-mail address: wan.wx1972@126.com (W. Wan).
}

ambient levels of $\mathrm{O}_{3}$ on plants in and around Beijing or anywhere else in China.

Older leaves of ozone-sensitive plants exhibit characteristic injury symptoms when $\mathrm{O}_{3}$ levels are high enough and exposure is long enough and environmental conditions are appropriate for gas exchange. Symptoms of ambient $\mathrm{O}_{3}$ injury on a wide variety of native plants have been observed in the field and then verified as being caused by $\mathrm{O}_{3}$ (Skelly et al., 1999; Innes et al., 2001; Porter, 2003; Manning and Godzik, 2004; Kohut, 2005; Davis, 2007; ICP Forests, 2010; Paoletti et al., 2009; Sanz and Catalayud, 2011). Using these references and pictorial data bases as a guide, symptom expression is a widely accepted and reliable method of assessing plant response to $\mathrm{O}_{3}$ in the field and providing biological significance for $\mathrm{O}_{3}$ monitoring data (Manning, 2003).

Coulson et al. (2003) rated tree species in mid-Atlantic States using $\mathrm{O}_{3}$ injury symptoms. The Carpathian Mountain Range was surveyed for $\mathrm{O}_{3}$ injury on plants over a 10-year period (Manning and Godzik, 2004). Davis (2007) and Davis and Orendovici (2006) used foliar $\mathrm{O}_{3}$ injury symptoms on plants as evidence of $\mathrm{O}_{3}$ injury to plants in Maine and Pennsylvania. Native bioindicator plants for $\mathrm{O}_{3}$ were extensively used in forest health monitoring programs over a16-year period in the Eastern USA (Smith et al., 2003, 2008; Smith, 2012). Ozone injury on ornamental plants has also been investigated in the field. Ozone symptom expression on Hibiscus 


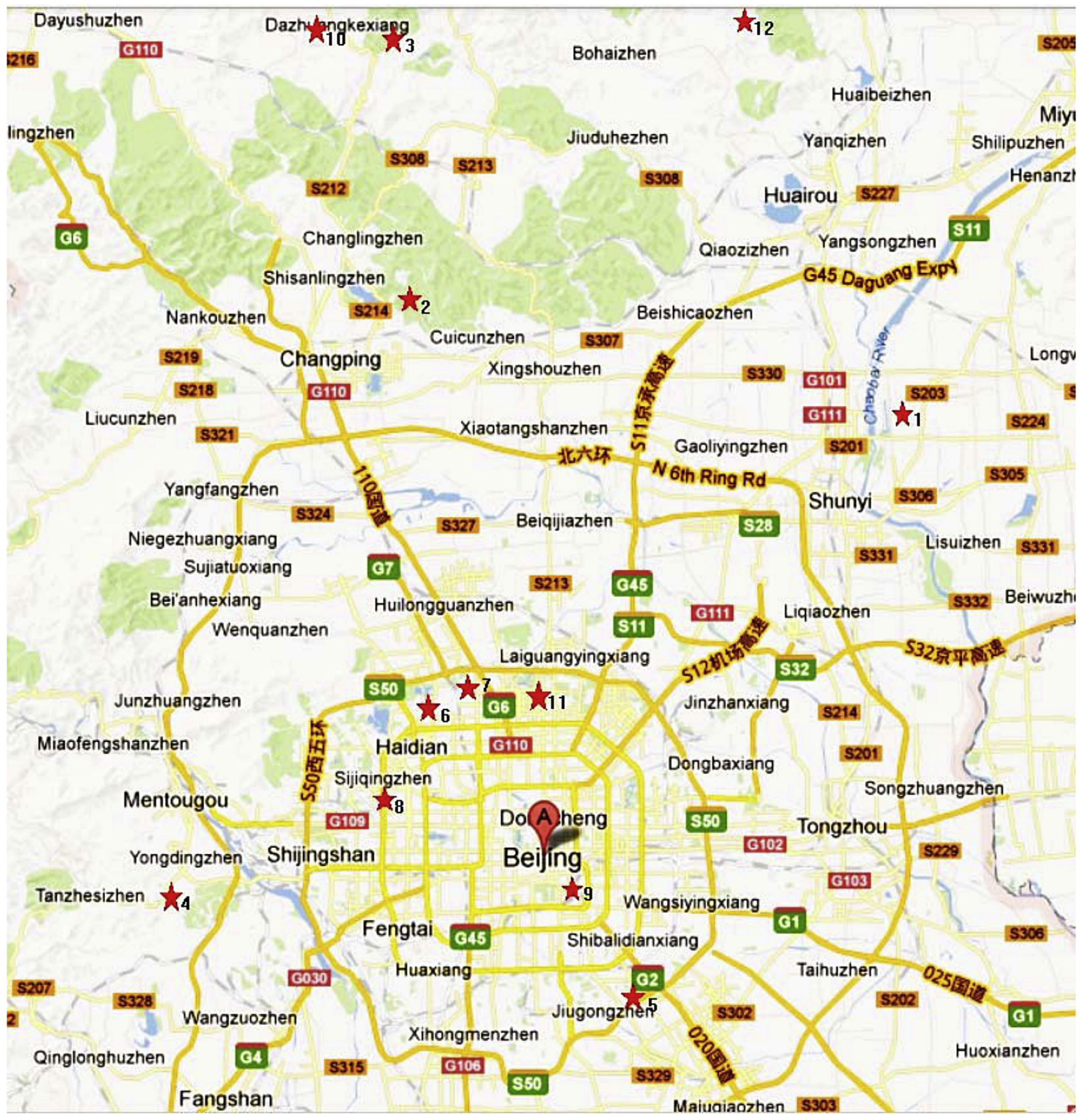

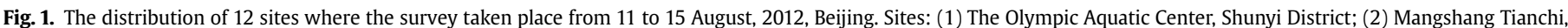

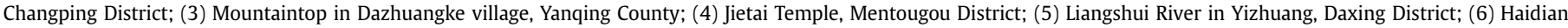

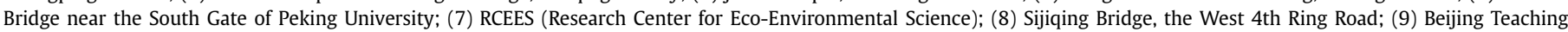

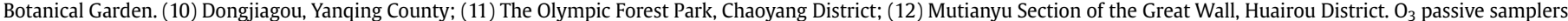
were set at sites $1-10$.

syriacus was detected in the field and verified by treatment of plants to EDU (ethylenediurea) and exposure of plants to $\mathrm{O}_{3}$ in open-top chambers (Paoletti et al., 2009).

Surveys for $\mathrm{O}_{3}$ injury on native plants have been combined with and located near passive $\mathrm{O}_{3}$ samplers or active real-time $\mathrm{O}_{3}$ analyzers (Manning et al., 1996; Yuska et al., 2003; Bytnerowicz et al.,
2004; Manning \& Godzik, 2004; Sager et al., 2005). This makes it possible to relate $\mathrm{O}_{3}$ injury symptoms on native plants to $\mathrm{O}_{3}$ exposure.

Here we report the results from our survey of native and cultivated plants at 10 study sites with $\mathrm{O}_{3}$ passive samplers and two additional sites without passive samplers in and around Beijing. 
Table 1

Environmental conditions and number of $\mathrm{O}_{3}$ injured species of the sites investigated.

\begin{tabular}{|c|c|c|c|c|c|}
\hline Sites & Locations & Elevation (m) & Land use & Dominant species & $\begin{array}{l}\text { Number of } \\
\text { injured species }\end{array}$ \\
\hline 1 & Aquatic center & 40 & Plantation & Populus tomentosa & 1 \\
\hline 2 & Tianchi & 587 & Natural secondary forest & Morus alba Ailanthus altissima Pinus tabuliformis & 7 \\
\hline 3 & Dazhuangke & 647 & Natural secondary forest & Rhamnus parvifolia Ailanthus altissima Juglans regia & 2 \\
\hline 4 & Jietai temple & 369 & Natural secondary forest & Pinus tabuliformis Pinus bungeana Sophora japonica & 3 \\
\hline 5 & Liangshui river & 36 & City riverside park & Morus alba Sophora japonica Rhus typhina & 6 \\
\hline 6 & Haidian bridge & 51 & City roadside park & Populus tomentosa Pinus tabuliformis Ginkgo biloba & 1 \\
\hline 7 & RCEES & 52 & City roadside trees & Platanus acerifolia Koelreuteria paniculata Sophora japonica & - \\
\hline 8 & Sijiqing bridge & 57 & City roadside park & Ginkgo biloba & - \\
\hline 9 & $\begin{array}{l}\text { Beijing teaching } \\
\text { botanical garden }\end{array}$ & 43 & City popular science park & Various cultivated plant species & - \\
\hline 10 & Dongjiagou & 620 & Shrubs and farmland & Quercus aliena Ulmus Macrocarpa Zea mays Glycine max & - \\
\hline 11 & Olympic forest park & 39 & City park & Populus tomentosa Ginkgo biloba Sophora aureus & 9 \\
\hline 12 & Mutianyu & 486 & Natural secondary forest & Ulmus pumila Sophora japonica Koelrenteria Paniculata & 3 \\
\hline
\end{tabular}

\section{Methods}

\subsection{Site selections}

The study was conducted in the urban region and peri-urban region of Beijing. The annual mean temperature is approximately $11-12{ }^{\circ} \mathrm{C}($ State Statistical Bureau, 2011). Mean annual precipitation is about $585 \mathrm{~mm}$, with more than 70\% occurring from June to August (Beijing Water Authority, 2010). The annual mean concentrations of $\mathrm{NO}_{2}, \mathrm{SO}_{2}, \mathrm{PM} 2.5$ and $\mathrm{O}_{3}$ were $21.5 \mathrm{ppb}, 9.76 \mathrm{ppb}, 71.8 \mu \mathrm{g} / \mathrm{m}^{3}$ and $22.1 \mathrm{ppb}$ from Nov. 1, 2008 to Oct. 30, 2009 (Wang et al., 2011). The $\mathrm{NO}_{2}, \mathrm{SO}_{2}$, and PM2.5 concentrations were higher in winter than in summer because coal burning for heating was the major pollution sources, while $\mathrm{O}_{3}$ concentration was higher in summer because of the good meteorological conditions for photochemical reactions to generate $\mathrm{O}_{3}$, with higher temperature, higher ultraviolet radiation and lower wind speed (Wang et al., 2011; Xu et al., 2011). The peak value usually occurred at 15:00 to $17: 00$ o'clock in the afternoon (Wang et al., 2011). Higher $\mathrm{O}_{3}$ concentrations during the growing period and the afternoon would cause greater uptake of $\mathrm{O}_{3}$ by plants, resulting in more injury and growth effects. From the $\mathrm{O}_{3}$ monitoring data in Beijing, Wang et al. (2012a,b,c) had estimated that the AOT40 (accumulated exposure over a threshold of $40 \mathrm{ppb}$ ) during growing season was $20.12 \mathrm{ppm} \mathrm{h}$, which far exceeded the AOT40 $5 \mathrm{ppm}$ h, the current critical level for ozone impacts on trees (UNECE, 2004), and the flux-based critical level $\mathrm{AF}_{\mathrm{st}} 1.6$ by five tree species reached $5.11-17.7 \mathrm{mmol} \mathrm{m}^{-2}$, exceeding the flux-based critical level for ozone impact trees (UNECE, 2004).

In this study, 12 sites were selected according to vegetation types and prevailing wind patterns (Fig. 1). The Sites 1, 2, 3, 4, 10 and 12 are natural generated forests dominated mainly by 3 tree species: Ulmus pumila, Morus alba and Ailanthus altissima. Around these sites, there were 3-5 shrub species, such as Grewia biloba var. parviflora, Prunus davidiana, and Cotinus coggygria var. pubescens and 15-20 herbaceous species. Other sites were park or roadside with cultivated plants and intensive managements with irrigation and fertilization, and were dominated by landscape plants, including trees (e.g., Populus tomentosa, Sophora japonica, Rhus typhina and Ginkgo biloba), shrubs (Amygdalus triloba, Kerria japonica var. plenifolia and Hibiscus syriacus) and many ornamental herbs. The location, elevation, land use and dominant species of these sites are showed in Table 1.

\section{2. $\mathrm{O}_{3}$ monitoring}

One Ogawa passive sampler (Ogawa \& Co. USA, Inc.) was installed at each of the study sites $1-10$. Filters were replaced at 1-week intervals from 11 July to 9 August, resulting in 3 data samples by the time the vegetation survey was begun on 11 August. Mean ambient $\mathrm{O}_{3}$ concentrations for each sampling location were statistically analyzed and used as an indicator of total $\mathrm{O}_{3}$ exposure (SPSS 16.0). At one of the sites (Beijing Teaching Botanical Garden) $\mathrm{O}_{3}$ was also continually monitored by a UV analyzer (Thermo Fisher 49i, Thermo Fisher Scientific Inc., USA). At site 2 (Tianchi), $\mathrm{O}_{3}$ was also measured with a UV analyzer of the same model before the start of the survey.

\subsection{Foliar $\mathrm{O}_{3}$ injury assessment}

Native and cultivated plants near the ten study sites with passive $\mathrm{O}_{3}$ samplers and the two additional sites without passive samplers (site 11, Olympic Forest Park and site 12, Mutianyu) were surveyed for foliar $\mathrm{O}_{3}$ injury from 11 to 15 August, 2012. Vegetation within $100 \mathrm{~m}$ from the passive samplers was surveyed for sites 110. Vegetation along roads was observed for sites 11 and 12.

The following criteria from the ICP Forests Manual part VIII, Assessment of Ozone Injury, were used to identify and characterize $\mathrm{O}_{3}$ injury on the plants that we surveyed:

"Ozone visible injury can be identified and distinguished from symptoms caused by other biotic/abiotic factors by the following criteria:

1. Visible symptoms are typically expressed as tiny purple-red, yellow or black spots (described as stipple) or sometimes as a general even discoloration, reddening or bronzing.

2. Look for ozone visible injury on fully developed, light-exposed leaves.

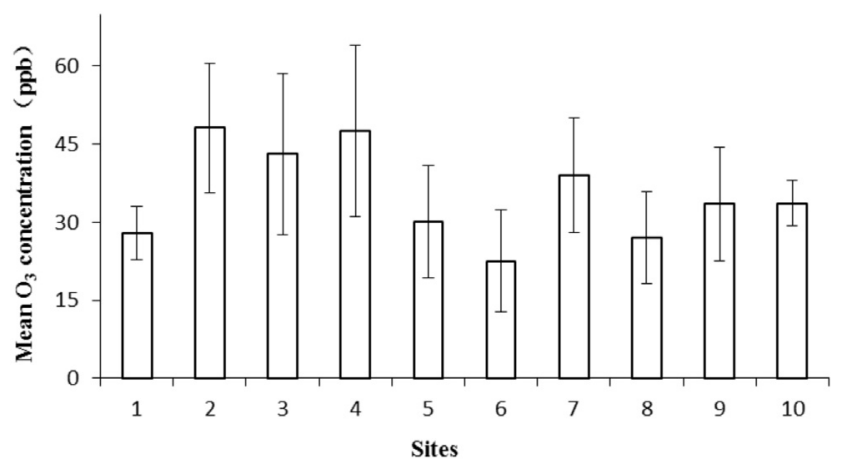

Fig. 2. Mean $\mathrm{O}_{3}$ concentration of 3 passive sampler data with 1-week intervals from 11 July to 9 August at study sites $1-10$ in 2012. The error bars are standard deviations. The location orders are the same as that in Fig. 1. 

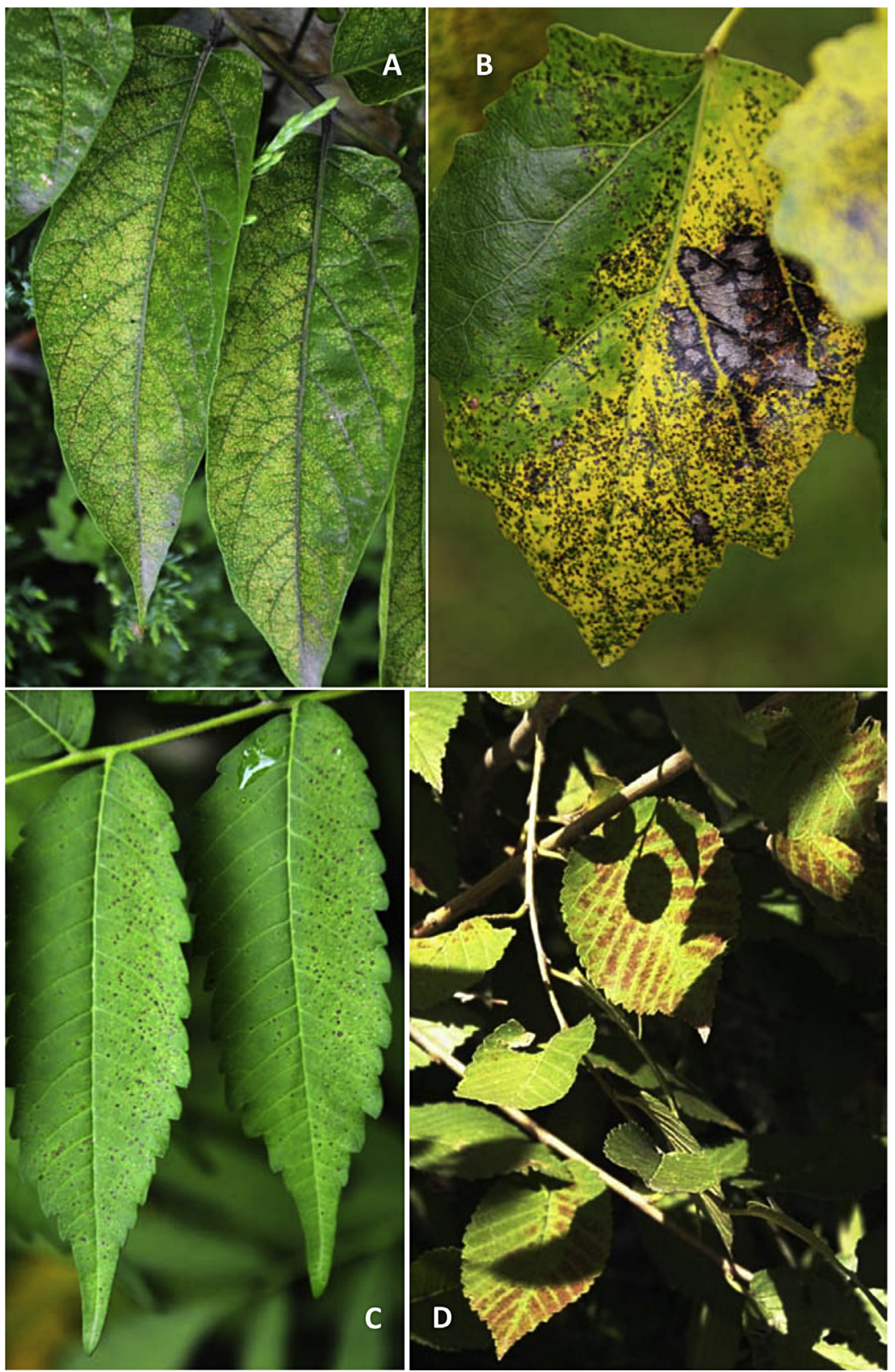

Fig. 3. The $\mathrm{O}_{3}$ injury symptoms on sensitive trees: (A) Ailanthus altissima, (B) Populus tomentosa, (C) Rhus typhina, (D) Ulmus pumila.

3. Symptoms are more severe on older middle-aged leaves than on younger leaves. Older leaves are the first ones to develop symptoms followed by accelerated senescence (age effect)

4. Shaded portions of two overlapping leaves do not show any visible injury (shade effect).

5. Ozone injury normally does not go through the leaf tissue. Both stippling and even discoloration occur only between veins (interveinal) and do not affect veins.

6. Towards the end of the growing season, foliar symptoms may progress to leaf yellowing or premature senescence, followed by leaf loss."

Based on the above information, the following questions should be answered when diagnosing possible ozone visible injury:

"Is there any stippling?
Is there any reddening and/or even discoloration?

Do the symptoms, as described above, occur on the upper leaf surface only (except during late season when visible injury becomes more severe and necrotic)?

Are the symptoms expressed between the veins only and are absent on the veins and veinlets (use hand lens and hold leaf against light)?

Are the symptoms evenly distributed?

Are the symptoms more developed on the older leaves (including leaflets, 'age effect')?".

If the above questions are answered affirmatively, the symptom can be considered as ozone visible injury.

Other handbooks, manuals and guides for identification of $\mathrm{O}_{3}$ injury symptoms on plants were also consulted (Innes et al., 2001; Porter, 2003; Kohut, 2005; Sanz and Calatayud, 2011; Smith, 2012). 


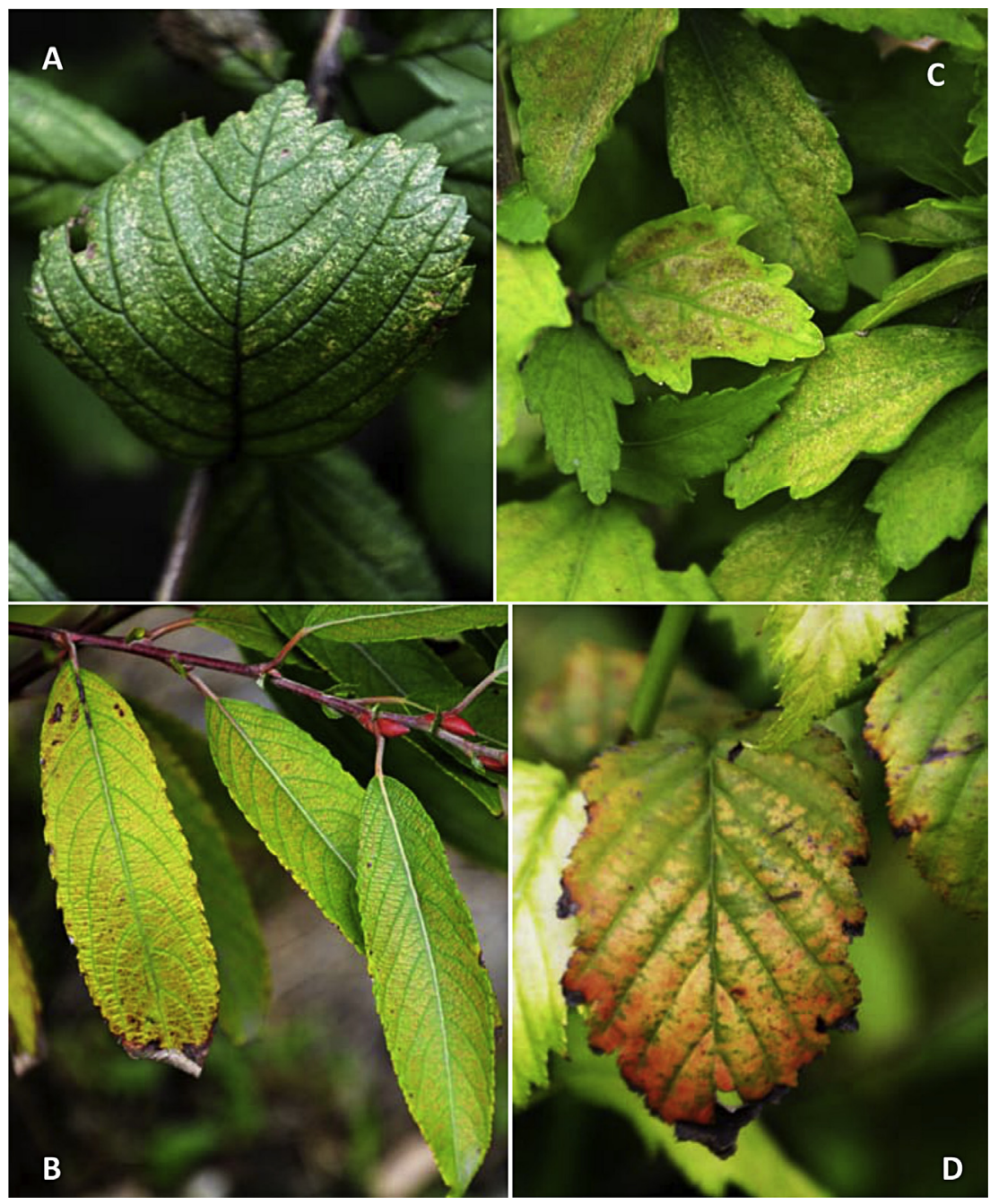

Fig. 4. The $\mathrm{O}_{3}$ injury symptoms on sensitive shrubs: (A) Amygdalus triloba, (B) Salix leucopithecia, (C) Hibiscus syriacus, (D) Kerria japonica var. pleniflora.

\section{Results}

\subsection{Ambient $\mathrm{O}_{3}$ concentrations}

Mean $\mathrm{O}_{3}$ concentrations derived from passive samplers varied significantly from 22.5 to $48.1 \mathrm{ppb}$ by sites during the month before the survey (Fig. 2). The highest concentrations occurred at sites 2, 3 and 4 . From 11 July to 9 August, $\mathrm{O}_{3}$ concentrations at site 9 (Beijing Teaching Botanical Garden) from the passive sampler and real-time analyzer were correlated (The coefficient of determination $R^{2}=0.56$ ). Results from site 2 (Tianchi) from the real-time analyzer (2-9 August) indicated a mean $\mathrm{O}_{3}$ concentration of $54 \mathrm{ppb}$, with a maximum value of $135 \mathrm{ppb}$. During the period of 2-9 August, hourly $\mathrm{O}_{3}$ concentrations exceeded $40 \mathrm{ppb}$ for $128 \mathrm{~h}$ and $80 \mathrm{ppb}$ for $17 \mathrm{~h}$. The real-time analyzer at site 2 showed that higher $\mathrm{O}_{3}$ concentrations occurred in May than August. The mean concentration was $74.4 \mathrm{ppb}$ from 21 to 31 May and the peak value of $195.8 \mathrm{ppb}$ occurred on 28 May.

\subsection{Ozone injury on plants}

Using the ICP Forests Criteria and questions during diagnoses, we found 19 species of native and cultivated trees, shrubs and herbs in and around Beijing that exhibited symptoms of foliar $\mathrm{O}_{3}$ injury
(Figs. 3-5). Upper surface stipple, ranging from white to yellow to brown to red to black was observed on 12 species (Table 2). "Classic stipple" was observed on leaves of Canavalia gladiata. Dark brown blotching was found on two species. Deep purple-brown older leaves were found on one species, interveinal chlorosis was observed on 3 species and general chlorosis on one species.

$\mathrm{O}_{3}$ injury was observed on plants at 6 of the 10 study sites and 2 of the additional sites that lacked passive samplers (Table 1). Frequency for foliar injury symptoms on the life forms were $56.3 \%$ (18/ 32 ) for trees, $15.6 \%$ (5/32) for shrubs, $21.9 \%$ (7/32) for herbs, $6.3 \%$ (2/ 32) for crop plants. Ailanthus altissima and Populus tomentosa occurred at 4 of the 12 sites. And Sophora japonica occurred at 3 of the 12 sites.

\subsection{Site differences for $\mathrm{O}_{3}$ injury}

There were significant differences in the number of species with $\mathrm{O}_{3}$ injury symptoms by site locations (Table 1 ). Site 2 (Tianchi) and site 3 (Dazhuangke) had high $\mathrm{O}_{3}$ levels and relatively higher occurrence of species with $\mathrm{O}_{3}$ injury symptoms. At sites $1,2,3,4$ and 6 , where were natural regenerated forest, the number of species with $\mathrm{O}_{3}$ injury symptoms increased with measured $\mathrm{O}_{3}$ concentrations. Site 5 , a riverside city park rich in landscape plants had the second largest number of foliar injured species observed with a 

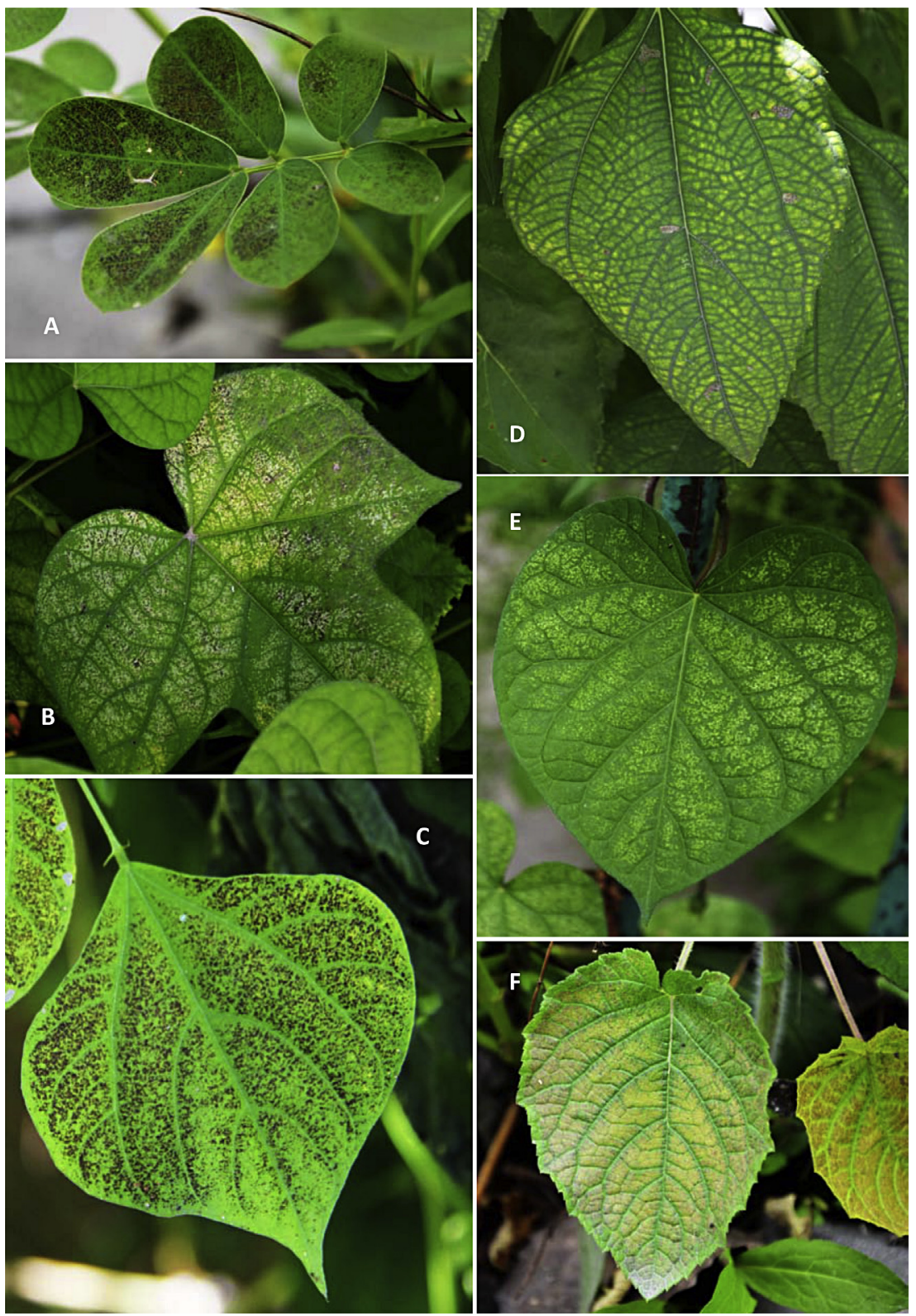

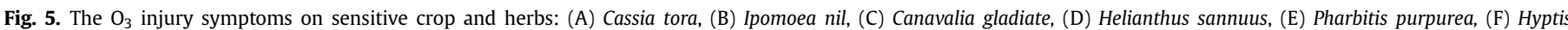
suaveolens.

middle level of mean $\mathrm{O}_{3}$ concentration. Site 11, the Olympic Forest Park, has extensive areas of cultivated ornamental plants. While $\mathrm{O}_{3}$ was not monitored there, the largest number of plant species with $\mathrm{O}_{3}$ injury was found there. Populus tomentosa, a widely planted native tree species, was the most sensitive plant. Extensive chlorosis and brown leaf blotching leading to defoliation was in progress. The Park is on the northern air flow gradient from central Beijing and should have high $\mathrm{O}_{3}$ concentrations given the large number of species affected and the intensity of the injury that occurred there.

\section{Discussion}

We were able to use passive $\mathrm{O}_{3}$ samplers to determine mean $\mathrm{O}_{3}$ concentrations at 10 study sites in and around Beijing in summer 2012. Passive samplers have been widely used by others in similar monitoring programs (Manning et al., 1996; Yuska et al., 2003;
Bytnerowicz et al., 2004; Sager et al., 2005). Good agreement was also found between results from the real time $\mathrm{O}_{3}$ analyzer and the passive sampler at Beijing Teaching Botanical Garden, validating the method (Yuska et al., 2003).

We also found that the highest average $\mathrm{O}_{3}$ concentrations were at locations outside the center of the city (Figs. 1 and 2). These results are consistent of other reports that indicate that $\mathrm{O}_{3}$ levels are often higher downwind of city centers. Mean concentrations were in the range $22.5-48.1 \mathrm{ppb}$, with highest values at sites 2,3 , and 4 . These values are only means and do not reflect high values that may have been episodically experienced. Data from real-time $\mathrm{O}_{3}$ analyzers showing the peak $\mathrm{O}_{3}$ concentration value of $198.5 \mathrm{ppb}$ and mean value of $74.4 \mathrm{ppb}$ which occurred in May were both higher than that of August. The time exceeded $40 \mathrm{ppb}$ and $80 \mathrm{ppb}$ were $128 \mathrm{~h}$ and $17 \mathrm{~h}$ separately during 2-9 in August on site 2. It revealed that plants in and around Beijing was frequently exposed to high ambient $\mathrm{O}_{3}$ concentration level. 
Table 2

Injury symptoms of $\mathrm{O}_{3}$ sensitive species in and around Beijing.

\begin{tabular}{|c|c|c|c|c|c|}
\hline \multirow[t]{2}{*}{ Injury symptoms } & \multirow[t]{2}{*}{ Species } & \multirow[t]{2}{*}{ Life form } & \multicolumn{2}{|c|}{$\mathrm{O}_{3}$ injury occurrence } & \multirow[t]{2}{*}{ Figures } \\
\hline & & & Sites no. & Frequency & \\
\hline \multirow[t]{10}{*}{ Yellow/brown to black stipple } & Ailanthus altissima & Tree & $2,3,4,12$ & 4 & Fig. 3A \\
\hline & Rhus typhina & Tree & 5 & 1 & Fig. $3 C$ \\
\hline & Juglans regina & Tree & 3 & 1 & - \\
\hline & Hibiscus syriacus & Shrub & 11 & 1 & Fig. 4C \\
\hline & Cassia tora & Herb & 11 & 1 & Fig. $5 \mathrm{~A}$ \\
\hline & Ipomoea nil & Herb & 4,5 & 2 & Fig. 5B \\
\hline & Phorbitis purpurea & Herb & 2,5 & 2 & Fig. $5 \mathrm{E}$ \\
\hline & Sophora japonica & Tree & $4,5,11$ & 3 & - \\
\hline & Sophora aureus & Tree & 11 & 1 & - \\
\hline & Canavalia gladiata & Crop & 2 & 1 & Fig. $5 \mathrm{C}$ \\
\hline \multirow{2}{*}{ White stipple } & Anygdalus triloba & Shrub & 2,11 & 2 & Fig. $4 \mathrm{~A}$ \\
\hline & Salix leucopithecia & Shrub & 11 & 1 & Fig. 4B \\
\hline \multirow{2}{*}{ Brown to dark mottle/blotch } & Populus tomentosa & Tree & $1,6,11,5$ & 4 & Fig. 3B \\
\hline & Ulmus pumila & Tree & 2,12 & 2 & Fig. 3D \\
\hline Dark brown leaves & Morus alba & Tree & 2,5 & 2 & - \\
\hline \multirow[t]{3}{*}{ Interveinal chlorosis } & Kerria japonica var. plenifolia & Shrub & 11 & 1 & Fig. 4D \\
\hline & Hyptis suaveolens & Herb & 11 & 1 & Fig. $5 \mathrm{~F}$ \\
\hline & Vigna unguiculata & Crop & 2 & 1 & - \\
\hline General chlorosis & Helianthus annuus & Herb & 12 & 1 & Fig. 5D \\
\hline
\end{tabular}

Much has been written and reported about air pollution and its effects on humans in Beijing (Wan et al., 2012), but this is the first report of $\mathrm{O}_{3}$ injury on plants in and around Beijing. This is evidence that not only are people at risk from air pollution in Beijing, but also is vegetation. Plants play an important part in ecosystem services in cities and anything that affects them will affect people. Finding $\mathrm{O}_{3}$ injury on plants in Beijing means that air quality is also not appropriate for humans. $\mathrm{O}_{3}$ injury on plants is a good bioindicator of relative $\mathrm{O}_{3}$ pollution levels.

Following established criteria for identifying foliar $\mathrm{O}_{3}$ injury in the field (Innes et al., 2001; Porter, 2003; Kohut, 2005; IPC Forests, 2010; Sanz and Calatayud, 2011; Smith, 2012), we identified 19 species of native and cultivated trees, shrubs, and herbs with $\mathrm{O}_{3}$ injury. Ailanthus altissima is a verified bioindicator plant for ambient $\mathrm{O}_{3}$ (Porter, 2003; Seiler, 2012) as is Hibiscus syriacus (Paoletti et al., 2009; Sanz and Calatayud, 2011). $\mathrm{O}_{3}$ injury has not previously been described for 9 species (Cassia tora, Phorbitis purpurea, Canavalia gladiata, Amgdalus triloba, Kerria japonica var. plenifolia, Hyptis suaveolens, Vigna unguiculata, and Sophora aureus and Juglans regina). Ozone injury on these plants should be verified with controlled exposure experiments.

Populus tomentosa is widely planted in Beijing and surrounding areas. This is the first report of $\mathrm{O}_{3}$ injury on leaves of $P$. tomentosa. Other species in the genus Populus are known to be $\mathrm{O}_{3}$ sensitive as well (Innes et al., 2001; Kohut, 2005; ICP Forests, 2010). There is a very large grove of $P$. tomentosa in the Olympic Forest Park. At the time of our survey, the older leaves on the trees were chlorotic with irregular brown blotches. Extensive premature defoliation was occurring with fallen leaves accumulating on the walkway.

The largest numbers of plants with $\mathrm{O}_{3}$ injury was found at site 11 and site 5, the Olympic Forest Park and the Liangshui Riverside Park. Both of the parks had more open space and more cultivated plants than the other sites. And they were irrigated during the growing season and this might increase $\mathrm{O}_{3}$ susceptibility in horticultural plants. None of the plants in 4 of the study sites $(7,8,9$, and 10) exhibited symptoms of $\mathrm{O}_{3}$ injury. Either sensitive plant species were not present. Except for site 7, $\mathrm{O}_{3}$ levels were lower (Figs. 1 and 2). Environmental conditions may also have not been conducive to $\mathrm{O}_{3}$ uptake by plants.

Although foliar $\mathrm{O}_{3}$ injury symptoms in field would be interfered by other stresses, such as nutrient deficiency, drought, insects and pests and other air pollutants, some specific identities of $\mathrm{O}_{3}$ injury on leaf make field observation possible. Basing on ICP Forests Manual part VIII, Assessment of Ozone Injury, and other handbooks, manuals and guides for identification of $\mathrm{O}_{3}$ injury symptoms on plants (Innes et al., 2001; Porter, 2003; Kohut, 2005; Sanz and Calatayud, 2011; Smith, 2012), we can justify calling what we observed as being $\mathrm{O}_{3}$ injury. $\mathrm{SO}_{2}$ injury only occurs on newer leaves and not older ones. The injury does not resemble $\mathrm{O}_{3}$ injury. $\mathrm{NO}_{2}$ injury also occurs on newer leaves and does not resemble $\mathrm{O}_{3}$ injury. $\mathrm{SO}_{2}$ injury might be possible, but levels of $\mathrm{NO}_{2}$ have to be quite high to cause injury. Particulates could not cause the kinds of injury that we observed. Nutrient deficiency caused chlorosis always appeared on the whole leaf. Fungi caused injury include veins. Insects' injuries were usually with traces of their biting or remnants, even the living insects. Basing on the criteria above, we could confirm at high confidential that the foliar injury symptoms we documented were caused by elevated $\mathrm{O}_{3}$ exposure.

\section{Conclusions}

$\mathrm{O}_{3}$ was assessed for the first time with passive samplers and with real-time analyzers in and around Beijing. Results indicate $\mathrm{O}_{3}$ levels of concern for plants and people. $\mathrm{O}_{3}$ injury on 19 plant species was found at 8 of the 12 sites surveyed. This is the first report of $\mathrm{O}_{3}$ injury to plants in this area. One of the sites, the Olympic Forest Park, is used extensively by residents of Beijing. Results from this short initial assessment provide justification for a much more extensive and long-term investigation of $\mathrm{O}_{3}$ and its effects on vegetation in and around Beijing and elsewhere in China.

\section{Acknowledgments}

The research has been supported by the National Natural Science Foundation of China (No. 31170424, 41030744). We thank the anonymous reviewers for their helpful comments on the earlier manuscript.

\section{References}

Beijing Water Authority, 2010. Beijing Water Resources Bulletin 2009. China Water and Hydropower Publisher, Beijing.

Bytnerowicz, A., Godzik, B., Grodzinska, K., Franzek, K., Musselman, R. Manning, W.J., Badea, O., Popescu, F., Fleisher, P., 2004. Ambient ozone in forests of the Central and Eastern European mountains. Environ. Pollut. 130, 5-16. 
Coulson, J.W., Smith, G.C., Smith, W.D., 2003. Regional assessment of ozone sensitive tree species using bioindicator plants. Environ. Monit. Assess. 83, 113-127.

Davis, D.D., 2007. Ozone-induced symptoms on vegetation within the Moosehorn National Wildlife Refuge in Maine. Northeast. Nat. 8, 403-414.

Davis, D.D., Orendovici, T., 2006. Incidence of ozone symptoms on vegetation within a National Wildlife Refuge in New Jersey, USA. Environ. Pollut. 143, 555-564.

ICP Forests, 2010. Assessment of Ozone Injury, Part VIII. http://icp-forests.net.

Innes, J.L., Skelly, J.M., Schaub, M., 2001. Ozone and Broadleaved Species. A Guide to the Identification of Ozone-induced Foliar Injury. Paul Haupt Publishing, Bern, Switzerland, ISBN 3-258-06384-2, 136 pp.

Kohut, R., 2005. Handbook for Assessment of Foliar Ozone Injury on Vegetation in the National Parks. National Park Service U.S. Department of the Interior. http:// www2.nature.nps/air/permits/aris/networks/docs/Handbook_Ozone_Injury_ Assessment.pdf.

Manning, W.J., 2003. Detecting plant effects is necessary to give biological significance to ambient ozone monitoring data and predictive ozone standards. Environ. Pollut. 126, 375-379.

Manning, W.J., Godzik, B., 2004. Bioindicator plants for ambient ozone in Central and Eastern Europe. Environ. Pollut. 130, 33-39.

Manning, W.J., Krupa, S.V., Bergweiler, C.J., Nelson, K.I., 1996. Ambient ozone in three class I wilderness areas in the northeastern USA: measurement with passive Ogawa samplers. Environ. Pollut. 91, 399-403.

Paoletti, E., Ferrara, A.M., Calatayud, V., Cervero, J., Gianetti, F., Sanz, M.J. Manning, W.J., 2009. Deciduous shrubs for ozone bioindication: Hibiscus syriacus as an example. Environ. Pollut. 157, 865-870.

Porter, E., 2003. Ozone Sensitive Plant Species on National Park Service and U.S. Fish and Wildlife Service Lands: Results of the 2003 Workshop, Baltimore MD. http://www2.nature.nps.gov/ard/pubs/index.htm.

Sager, E.P.S., Hutchinson, T.C., Croley, T.R., 2005. Foliar phenolics in sugar maple (Acer Saccharum) as a potential indicator of tropospheric ozone pollution. Environ. Monit. Assess. 105, 419-430.

Sanz, M.J., Calatayud, V., 2011. Ozone Injury in European Forest Species. http:// ozone injury.org.

Seiler, L.S., 2012. Effectiveness of Ailanthus altissima as a Bioindicator of Ozone Pollution (M.S. thesis). The Pennsylvania State University.

Skelly, J.M., Innes, J.L., Savage, J.E., Snyder, K.R., Vanderheyden, D., Zhang, J., Sanz, M.J., 1999. Observation and confirmation of foliar ozone symptoms of native plant species of Switzerland and Southern Spain. Water Air Soil. Pollut. $116,227-234$

Smith, G., 2012. Ambient ozone injury to forest plants in Northeast and North Central USA: 16 years of biomonitoring. Environ. Monit. Assess. 184, 40494065.
Smith, G., Coulston, J., Jepsen, E., Prichard, T., 2003. A national ozone biomonitoring program - results from field surveys of ozone sensitive plants in northeastern forests (1994-2000). Environ. Monit. Assess. 87, 271-291.

Smith, G.C., Coulston, J.W., O'Connell, B.M., 2008. Ozone Bioindicators and Forest Health: a Guide to the Evaluation, Analysis, and Interpretation of Ozone Injury Data in the Forest Inventory and Analysis Program. Gen. Tech. Rep. NRS-34. U. S. Dep. Agric. For. Serv. North. Res. Stn., Newt. Square, PA, p. 34.

State Statistical Bureau, 2011. Statistical Yearbook of Beijing 2010. China Statistics Press, Beijing.

Tang, G., Li, X., Wang, Y., Xin, J., Ren, X., 2009. Surface ozone trend details and interpretations in Beijing, 2001-2006. Atmospheric Chem. Phys. 9, 8813-8823.

Tang, H., Liu, G., Han, Y., Zhu, J.G., Kobayashi, K., 2011. A system for free-air ozone concentration elevation with rice and wheat: control performance and ozone exposure regime. Atmos. Environ. 45, 6276-6282.

UNECE, 2004. Revised Manual on Methodologies and Criteria for Mapping Critical Levels/loads and Geographical Areas Where They Are Exceeded. www. icpmapping.org (February 12, 2006).

Wan, W., Xie, X.X., Zhang, S.Q., 2012. Health effect valuation of ground-level ozone control in Beijing and its surrounding areas, China. Adv. Mater. Res. 356, 585-589.

Wang, J., Zhang, H.X., Wang, X.K., Mou, Y.J., 2011. Study on air pollutants in three representative regions of Beijing. Environ. Chem. 30, 2047-2053.

Wang, X., Manning, W.J., Feng, Z., Yongguan, Zhu, 2007. Ground-level ozone in China: distribution and its effects on crop yields. Environ. Pollut. 147, 394-400.

Wang, H., Zhou, W., Wang, X., Gao, F., Zheng, H., Tong, L., Ouyang, Z., 2012a. Ozone uptake by adult urban trees based on sap flow measurement. Environ. Pollut. 162, 275-286.

Wang, Y., Konopka, P., Liu, Y., Chen, H., Müller, R., Plöger, F., Riese, M., Cai, Z., Lü, D. 2012b. Tropospheric ozone trend over Beijing from 2002-2010: ozonesonde measurements and modeling analysis. Atmos. Chem. Phys. 12, 8389-8399.

Wang, X.K., Zhang, O.Q. Zheng, F.X., Zheng, O.W. Yao, F.F. Chen, Z., Zhang, W.W. Hou, P.Q., Feng, Z.Z., Song, W.Z., Feng, Z.W., Lu, F., 2012c. Effects of elevated O concentration on winter wheat and rice yields in the Yangtze River Delta, China. Environ. Pollut. 171, 118-125.

Xu, J., Zhang, X., Xu, X., Zhao, X., Meng W. Pu, W. 2011. Measurement of surface ozone and its precursors in urban and rural sites in Beijing. Proc. Earth Planet. Sci. 2, 255-261.

Xu, J., Zhang, Y.H., 2006. Process analysis of $\mathrm{O}_{3}$ formation in summer at Beijing. Acta Sci. Circumstantiae 26, 973-980.

Yuska, D.E., Skelly, J.M., Ferdinand, J.A., Stevenson, R.E., Savage, J.E., Mulik, J.D. Hines, A., 2003. Use of bioindicators and passive sampling devices to evaluate ambient ozone concentrations in north central Pennsylvania. Environ. Pollut. 125, 71-80. 